\title{
Technical Writing - Redefining the English syllabus to meet the Growing Demand for competent Engineers
}

\author{
Ms. Evangeline. JCK., Dr. Ganesh. K \\ ${ }^{1}$ Ph.D Research Scholar, Department of English, Sathyabama University, Chennai, India \\ ${ }^{2}$ Associate Professor, Department of English, Madras Christian College, Chennai, India
}

\begin{abstract}
Universities are expected to develop world-class human resources to meet global development challenges. This challenge is a response to the advancements in the field of information and technology. This should be reflected in the curriculum of engineering programs, to make them a saleable product in the competitive work field. The study analyses the syllabi of ten technical universities and reviews the need for a paradigm shift in the present engineering curriculum. The trajectory of the development of "Technical Writing," and how it differs from the traditional "Technical Communication" is explored. This paper also advocates the possible change for the future, which further increases diverse opportunities available for the potential engineers.
\end{abstract}

Key Words: Technical writing, Outcome-based learning, Curriculum, knowledge and skill

\section{Introduction}

English is no longer considered as a subject in the curriculum but is a skill to be inculcated to succeed, and an essential learning tool. Years before, language was viewed as a set of rules. It was thought that grammar rules automatically generate sentences, without utilizing the speaker's intuitive knowledge in the process. But now, it is important to distinguish between language used as a formal system and language used as a set of communicative events. A shift of emphasis is needed from teaching second language as a formal system, to teaching second language as communication. It is necessary to learn to use the second language meaningfully in various situations. In other words, for a language learner, to know a language is not only to know the rules of its grammar, but also to know how to use them in appropriate places in appropriate ways.

Teachers of English should keep in mind the growing need for English skills while designing the English syllabus and in adapting the right methodology of teaching English to technical students. Outcomes based education is a process that involves the restructuring of curriculum, assessment and reporting practices in education to reflect the achievement of high order learning and mastery rather than the accumulation of course credits" (Tucker, 2004). By investigating the present syllabi followed in a few Technical universities, the factors for developing the ability of the students to perform in written communicative functions can be analyzed. The suggestions given thereupon would help the students to develop the written communication skills to meet the industrial demands.

\section{Role of syllabus in teaching:}

The syllabus for language learning defines the goals in terms of speaking, listening, reading, or writing skills. The role of the instructional materials within a functional/commutative methodology might be specified in the following terms:

a. should focus on the communicative abilities of interpretation, expression and negotiation.

b. should be on understandable, relevant, and interesting exchanges of information rather than on the presentation of grammatical form, and

c. should involve different kinds of texts and media, which the learners can use to develop their competence through a variety of activities and tasks.

\section{Present Syllabi}

Almost all the technical universities, including Anna University and its affiliated colleges, offer Technical English as one of the common papers for the first year engineering students. Nevertheless, what is the objective of Technical English having been introduced in the curriculum of Technical English Teaching (TET) for engineering university students? "These are more English communication and grammar classes rather than technical writing sessions. These do not train the prospective engineers to write good projects, documents or proposals." (Kannan, 2013) 


\section{Comparison of Syllabi}

\begin{tabular}{|c|l|l|l|l|}
\hline Sl. No. & University & $\begin{array}{l}\text { No. of Semesters with English as } \\
\text { a paper }\end{array}$ & $\begin{array}{l}\text { No. of Topics to test } \\
\text { Grammar ability }\end{array}$ & $\begin{array}{l}\text { No. of Topics to test the } \\
\text { writing skill }\end{array}$ \\
\hline 1. & AU & 2 & 15 & 6 \\
\hline 2 & HU & 2 & 26 & 9 \\
\hline 3 & JU & 1 & 11 & 3 \\
\hline 4 & KU & 3 & 10 & 12 \\
\hline 5 & KU & 2 & 23 & 14 \\
\hline 6 & LU & 1 & 13 & 8 \\
\hline 7 & MU & 1 & 18 & 5 \\
\hline 8 & SU & 1 & 15 & 6 \\
\hline 9 & TU & 2 & 15 & 7 \\
\hline 10 & VU & 2 & 9 & 7 \\
\hline
\end{tabular}

[As it is not the intention of the authours to comment on the syllabi followed by the universities, names of the universities are omitted purposely.]

In the pretext of focusing on writing, universities tend to focus more on grammar rather than on real writing. It is very important to remember that grammar is only a component in learning a language, but not a skill. What the budding engineers require is the skill of writing. Most of the universities, especially the private universities, seem to have English as a paper only for one semester in the whole engineering course. Though a few universities seem to offer special papers such as 'Creative Writing', 'Communicative English', and 'Business English', those papers are optional papers, for the students to choose from; where students as almost always choose the one that would fetch them more marks without much of hassle.

As per the report after a job fair, in the Hindu on the requirements of multinational companies the following is the condition at the placement front. As most of the communication in the industrial and allied sectors - the future work-place of the engineering students - happen mostly through writing, industries set more weight on testing the writing skill during the selection process and speaking takes the second place. It is rather a complaint from the companies that though the candidates prove to be excellent in academics, they lack communicative skills. One of the most important 'employable skills' being 'communicative skills', many reputed companies could pick only a handful of candidates though they required many. The following table presents the requirements and the actual number of people who were hired at the job fair in Chennai.

\begin{tabular}{|l|l|l|}
\hline Company & Requirement & Hired \\
\hline HCL Investment Banking BPO & 1000 & 30 \\
\hline ICICI on Source & 1000 & 30 \\
\hline Cognizant & 1000 & 40 \\
\hline 24X7 Customer & $300-350$ per month & 21 \\
\hline Sutherland global Services & 400 per month & 25 \\
\hline Allsec Technologies & 6400 & 20 \\
\hline Coimbatore Transcription Industry association & 1000 & Nil \\
\hline Wipro & 1000 & Nil \\
\hline
\end{tabular}

(qtd. in Sripada, 2008)

\section{Salient Features of the new syllabus:}

The new syllabus should bring in a desired outcome from the part of the learners. As Spady rightly puts it, Outcome based learning is "clearly focusing and organizing everything in the education system around what is essential for all students to be able to do successfully at the end of their learning experiences. This means starting with a clear picture of what is important for students to be able to do, then organising the curriculum, instruction and assessment to make sure that learning ultimately happens" (Spady, 1994, p.1). The syllabus should fulfill the learners' immediate needs - academic purpose (EAP) and for future time when they go to their jobs - occupational purpose (EOP).

Language teachers in Engineering colleges may feel perturbed about implementing practices that are aimed at developing learner independence in an academic setting, where students' attention is largely focused on completing technical curriculum. When teachers deal with such technical students, it becomes nearly mandatory that the English teachers revamp the syllabus right from the start in order to cater to the needs of technical students. The approach of "Content and Language Integrated Learning" (CLIL) in teaching would be the best solution for this. 


\section{Technology in Technical Writing:}

Many teachers still believe in the myth of silent class being a good class. They also seem to be happy and satisfied if they could keep a class silent. Teachers feel comfortable in following lecture method, or black board-chalk method of teaching. As a result, the students who are taught to write the coding in computer language, at times, finds it difficult even to prepare a good power point presentation. The curriculum should aim at developing the communicative capability of the technical graduates on technical matters.

Further, the teacher should move forward to attract students to increase their writing capability by providing them opportunities to write something over and above what is not prescribed or mandated in a course. Using a tool that the students are already comfortable with - such as mobile phone and internet - is a quick approach. The technical students, who love to spend more time with the technology, should be encouraged to use the same in improving their communicative skills as well. This would ultimately propel the students to achieve language proficiency and communicative competency through continuous participative and performance tasks.

\section{Conclusion}

Writing is supposed to be the essential skill and component prescribed in the syllabus for technical students, because most of the communication in their work-place takes place only through writing. The objective of analyzing the syllabi is that the change would help the students to be essentially communicative in general and technical contexts in written communication. According to the authors, such paradigm shifts should happen at different levels, i.e., at the levels of undergraduate degrees, and continuing professional education. If we really want our teaching to be more effective, our approach should be considerate and encouraging. Teachers need to ensure that there is genuine learning and also to help the learner to think critically, creatively and practically. Therefore, the need of the day is to make existing teaching process more effective.

\section{Reference}

[1]. Kannan, A. (2013, January 31). Technical writing fails to impress as a career. Retrieved from The Hindu: http://www.thehindu.com/todays-paper/tp-national/tp-tamilnadu/technical-writing-fails-to-impress-as-a-career/article4363534.ece

[2]. Spady, W. (1994). Outcomes Based Education: Critical Issues and Answers. American Association of School Administration: Arlington, Virginia.

[3]. Sripada, P. (2008). Strategies to Improve the Vocabulary of Students at Tertiary Level: an Experimental Study and Sample Material. Chennai: Sathyabama University.

[4]. Tucker, B. (2004). Literature Review: Outcomes-focused Education in Universities. Learning Support Network, Curtin University of Technology. Retrieved November 4, 2013, from http://lsn.curtin.edu.au/outcomes/docs/LitReview.pdf 